Pchela Yu.V.,

Student of Magistrate Bohdan Khmelnitskiy Melitopol State Pedagogical University

\title{
THEMES CREATING THE CONCEPT OF AMERICAN DREAM IN THE NOVEL “THE GRAPES OF WRATH” BY JOHN STEINBECK
}

Summary. The article has been devoted to the disclosure of themes creating the concept of the American Dream in the novel "The Grapes of Wrath" by an American writer of the 20th century John Steinbeck. The story of the emergence of the concept of the American Dream is briefly given. The description and analysis of the constituents of the American Dream concept is presented. The authors of the article explain how the themes revealed in the novel "The Grapes of Wrath" shape the national identity in the time of crisis.

Also the causes of creating the novel by J. Steinbeck are explained. The difference of American Dream from other Dreams is described. The authors made attempt to analyse the main components of American Dream concept given by different scholars. The paper presents the components of the American Dream concept, represented by various linguists and literary critics. Analysis of John Steinbeck's novel "The Grapes of Wrath" gives a reason to believe that the American Dream is a powerful idea, containing a display of frequent themes a deeper look into which provides insights into preserving national identity in times of crisis. The study presented the authors' own Model of self-reliant person hierarchy, based on themes that create the concept of the American Dream: "Faith", "Land as a source of identity", "On the road", "Unity" and "Knowledge to transform the world".

Each of the themes is analyzed and supported by the corresponding illustrations from the text of the novel. The authors consider that the theme of faith is the basic one, because people cannot survive without faith; being on the road is a constant process in human existence for searching better living conditions; only united people can be strong enough to stand their rights; and knowledge is a great power to transform the world for the better.

Key words: concept, American Dream, faith, land, road, unity, knowledge, independence.

The problem and its connection with important scientific and practical tasks. As the humanity is entering a new round of uncertainty, peoples are looking for the spiritual anchors to withstand economic, political, social, and cultural pressure and to preserve their identity. Fortunately for the United States, they have the national idea that was inspiring for many generations and has not lost its relevance up to date. In this article, we describe and analyze the tenets of the American Dream and explain how they shape the national identity in the time of crisis.

Analysis of the recent publications on the issue being under consideration. According to L. Reed [9], the concept of "Amer- ican Dream" began in the $1600 \mathrm{~s}$, when a new continent, where people could be free and not subjected to government persecution, began to attract the attention of Europeans. Proponents of the later emergence of the "American Idea" D. Miller [11], H. Hugen [8] and $\mathrm{H}$. Brown [6] believe that the concept is associated with immigrants who arrived in the United States at the end of the XIX century in search of a better life. European emigration was most active in the years 1820-1975.

Golenpolsky T.G. and Shestakov V.P. cite S. Holbuk's opinion: "The first recorded "American Dream", - writes the American researcher, was the dream of a small ship crossing the raging ocean with passengers on board who could hardly believe that the day came when they would be remembered as pioneers, and the "Mayflower" would symbolize the "birth certificate" of the American democracy" [1, p. 71].

J.A. Truslow described the "American Dream" as the...dream of a land in which life should be better and richer and fuller for everyone, with opportunity for each according to ability or achievement. It is a dream of social order in which each man and each woman shall be able to attain to the fullest stature of which they are innately capable, and be recognized by others for what they are, regardless of the fortuitous circumstances of birth or position [18].

We could find references to the concept of American Dream in "The Autobiography of Benjamin Franklin", "The True Story of a Great Life", the biography of Abraham Lincoln and other works about the life of the Founding Fathers. Although the idea behind the American Dream seems simple and straightforward, it still has many interpretations which may cause confusion in a reader.

The aim of the paper. By relying on an in-depth analysis of John Steinbeck's award-winning novel "The Grapes of Wrath", we seek to define and describe recurring themes, creating the concept of American Dream in the novel and its hierarchy.

The body of the paper. The novel "The Grapes of Wrath" was published in 1939, immediately after the end of the Great Depression, the deepest and, probably, the most severe, economic crisis in the $20^{\text {th }}$ century history. Millions of Americans were forced to leave their native places searching for job elsewhere. The biographer J. Parini admits that Steinbeck was among those migrants but moved in an opposite direction: from New York, where he tried to start the writing career, back to the birth home in California [13].

For some reasons, every nation has a dream that may be very similar to the dream that other peoples nurture and strive to accomplish. Nevertheless, American Dream is different from Le Reve 
Francais, Australian Dream, and other dreams a detailed description of which is found in literature. According to R.J. Shiller [14], the main difference is in the unique capability of the American Dream to stay relevant, regardless of the circumstances. The American Dream inspired the Americans during the Roaring Twenties but it was also encouraging when the country plunged into the Great Depression. The spiritual power of the American Dream encourages an in-depth look into the ideas constructing it.

N.V. Popova believes that the "American Dream" in its essence does not undergo fundamental changes over time, despite historical, sociocultural, and economic events, retains the basic idea, the ideal that was believed by immigrants and founding fathers [3, p. 42-46].

Many researchers have attempted to identify the main components of the "American Dream". For example, A.M. Zverev wrote about the "three pillars of the American Dream": 1) faith that the resources of American land are vast, and the material abundance is destined here to all without exception; 2) the conviction that only in America a person becomes free from class, social, ideological, educational and other restrictions; 3) confidence that in America the right to happiness is granted to everyone, and the chances of achieving happiness are absolutely equal for everyone [2, p. 171].

And according to foreign researchers, J. Bragg and M. Drayton, the concept of "American Dream" includes: 1) belief in the sustainable development of individual, collective, social conditions of existence, faith in progress; 2) conviction that everyone can realize his / her ambitions due to his / her own efforts; 3) confidence that America is a God-chosen country, whose purpose is to call the whole world to the American style of democracy; 4) the realization that the American form of power "for the people" is the only guarantee of freedom and equality; 5) the idea associated with people of different cultures: people can live peacefully, accepting the characteristics and culture of other people. This is a belief in multiculturalism, cultural and ethnic pluralism [4, p. 4-5].

$\mathrm{N}$. Popova summarized the data and identified three domains of "American Dream" concept: religious, ethical and political [3, p. 42].

Analysis of John Steinbeck's novel "The Grapes of Wrath" gives us a reason to believe that the American Dream is a powerful idea, containing an array of recurring themes a deeper look into which provides insights into preserving national identity in times of crisis. While reading the novel, we paid special attention to the recurring themes introduced in the narrative and intercalary parts and pertaining to self-reliance as a way to live the national dream. In our opinion, there are five recurring themes, constituting the dream behind a self-reliant man's identity (Scheme 1). We present these themes in the form of a pyramid (from the bottom to the top): "Faith", "Land as a source of identity", "On the road", "Unity", and "Knowledge to transform the world".

Faith. We think that the theme of faith is the basic in the novel under analysis. Moreover, some experts tend to examine "The Grapes of Wrath" through Biblical parallelism. For instance, S.M. Shockley [15] interpreted Jim Casy as a Christ figure, while J. Fortenrose believed there was a parallel between Tom Joad and Moses [7, p. 71-86].

We put forward an assumption that the theme of faith goes beyond adherence to a religious tradition and encompasses a firm trust in a man's spirit and unlimited human potential. In "The Grapes of Wrath", we could find many examples where faith takes the form of religious humanism, a philosophical approach that simultaneously stresses the single individual's needs and the role of the cove- nanted community [12]. Jim Casy protests when someone calls him reverend because he «was a preacher» but there is no "sperit ain't in me no more" [16, p. 12]. Therefore, he makes up his mind to stop preaching and join Okies making their way to California.

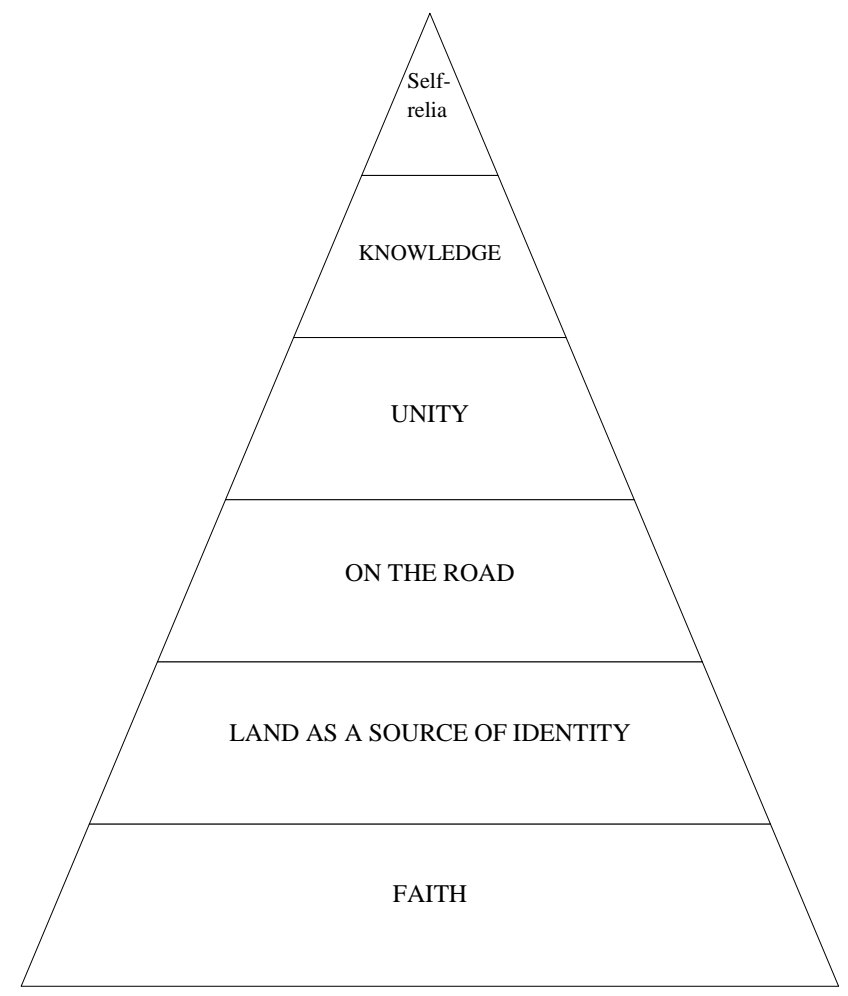

\section{Scheme 1. Model of self-reliant person hierarchy}

An important thing about faith is that it emerges from Casy's living side-by-side with people, learning from them, and understanding their needs. Eventually, Casy creates his own religious philosophy underlining the importance of individual and community needs. The essence of this philosophy is in the conversation between Casy and Mrs. Wilson comparing religious rituals with secular activities aimed at pleasing people: "They wasn't nothin' got between me an'them. An'-that's why I wanted to pray. I wanted to feel that clostness, oncet more. It's the same thing, singin' an 'prayin', jus' the same thing" [16, p. 148].

Faith going beyond religious awe, blind obedience to longstanding rites, and unconditional obedience to religious authorities, and aimed at meeting people's needs and making them happy is an important component in the hierarchy of ideas shaping a self-resilient individual with a dream.

Land as a Source of Identity. We discovered that land as a constituent of one's identity was among the recurring themes in "The Grapes of Wrath". In the novel, land is treated as a living being, the source of one's identity and spiritual strength. For farmers, land is the alpha and omega of their existence, therefore they are bewildered when the tractor men approach their possessions: "And when a horse stops work and goes into the barn there is a life and a vitality left, there is a breathing and a warmth, and the feet on the straw, and the jaws clamp on the hay, and the heat and smell of life. But when the motor of a tractor stops, it is as dead as the ore it came from" [16, p. 77].

When we dived into the theme, we concluded that Okies' reverent attitude to the land was not so much due to economic but psy- 
chological and spiritual reasons. Although there are many references in "The Grapes of Wrath" supporting the idea, we assume that the most impressive one appears in the episode, describing the tractor men coming to miserable debtors and plowing the land that used to be their home: "But the machine man, driving a dead tractor on land he does not know and love, understands only chemistry; and he is contemptuous of the land and of himself. When the corrugated iron doors are shut, he goes home, and his home is not the land" [16, p. 78].

We believe that the opposition between the tractor man, the man of the iron, and the farmer, the man of the land, is introduced in the novel to reveal the sense of being a self-reliant man of the changing era. Self-reliance means knowing the place to belong and transform it with own hands: "The last clear function of man - muscles aching to work, minds aching to create beyond the single need - this is man. To build a wall, to build a house, a dam, and in the wall and house and dam to put something of Manself' [16, pp. 100-101]. The place one belongs to constructs a unique identity by providing opportunities for manifesting the Manself.

On the Road. As people are forced off their land, they have to find another way to self-reliance, and being on the road appears one of them. So far, scholars have done an extensive research on the "little stories" of migrant life that constitute an essential element of Steinbeck's narration [17, p. 2]. The intertextual analysis attracts special interest to "The Grapes of Wrath" that seems to be a "concentrated' representation of the theme. G. Toth [17] analysed the Joads' trip in terms of the references to the Lakota and Chyenne myths of finding the new land. Being on the road is interpreted as payment for previously committed sins: "Grampa took up the land, and he had to kill the Indians and drive them away. And Pa was born here, and he killed weeds and snakes" [16, p. 34].

Therefore, we could notice that little to no attention in scholarly literature was paid to the road as a means of constructing one's identity and becoming a better self.

Meantime, we were able to find many references in "The Grapes of Wrath" suggesting that the road is the medium where the self-reliant man emerges. Such interpretation appears in the conversation between the Joads and Casy noting that: "They's movement now. People moving. We know why, an'we know how. Movin' cause they got to... Movin' cause they want somepin better' $n$ what they got. An' that's the on' $y$ way they'll ever git it" [16, p. 85].

In addition to bringing people from the dusty Great Planes to green California, where the work is plenty, the road provides ample opportunities for enhancing spiritual strength. Steinbeck admits that moving from place and place molded migrants in one way or another: "...road became their home and movement was the medium of their expression" [16, p. 109].

In some sense, being on the road means leaving one's comfort zone and learning things one did not know before: farmers learn to build roads and young people learn to be cotton pickers. For Connie and Al Joad, moving to California is a way to getting something better by learning a profession that is very different from what they did in the Great Planes.

However, the road itself becomes the place to reconstruct one's identity through interactions with other people. This is particularly evident in the case of Reverend Casy who follows the Joads to become an Emersonian thinker [17]. Like everyone in the family, Casy pays much attention to the roadside stories told by labor migrants as the way to learn the changing country and re-find one's place in it. In "The Grapes of Wrath", stories of the Okies' journey through the desert "presented at the time as a work of history", which was the context for becoming a self-reliant individual. In our conceptual model, being on the road is a place to reconstruct one's identity to become self-reliant rather than moving from economically disadvantaged areas to fertile Californian lands.

Unity. While analyzing the roadside stories and narrative parts, we could also identify a recurring theme of unity. The theme appears throughout the novel and aims to underline the potential of community to cope with the hardships of migration and revive one's spirit. By meeting the Wilsons and other migrants, some of which have been deeply disappointed in their Californian dream and are on their way home, the Joads realize the power of human involvement when: "...the twenty families became one family, the children were the children of all. The loss of home became one loss, and the golden time in the West was one dream..." [16, p. 131].

As the Joads get help from the Wilsons, they are ready to continue the chain of good deeds by feeding people in the labor camp, one of the forced stops on their way to a better life.

It is indisputable that the community of people united by a common dream to earn decent living is a source of strength and resilience. For authorities, the western states constitute a serious problem as: "The danger is here, for two men are not as lonely and perplexed as one. And from this «we» there grows a still more dangerous thing "I have little food» plus "I have none". If from this problem the sum is "We have a little food", the thing is on its way, the movement has direction" [16, p. 101]. Being part of community makes one voice their concerns and demand their rights being respected, which is the reason why authorities fear migrant camps and use every excuse to destroy them.

When analysing "The Grapes of Wrath", we hypothesized that the theme of unity is best revealed in a kind of antagonism between Noah Joad and Jim Casy. The oldest son of Joads, Noah is the first to stop the journey and experience «the oneness with the natural environment» by fishing on the Colorado River [17]. Noah's decision puzzles the family, although they credit his birth trauma and acting "strange" at various points of his life. At the same time, the Joads never hesitate to take Jim Casy with them when moving to California, even despite his reassurances that he is no longer a preacher and may be a burden to the family.

Somehow the Joads realize that being a unity, even though it consists of a "useless»» preacher, valetudinarian Rose of Sharon, and ill grandparents, will make them more resilient. We believe that comparison between Noah Joad and Jim Casy is a strong counterargument for the American Dream being individualistic, promoting consumerism and eventually leading to decay. In such interpretation, the American Dream can stand the test of time and make the country great again with the help of collective consciousness.

Knowledge to Transform the World. In our conceptual model, we put knowledge on the top of the self-reliant man hierarchy for several reasons. The most obvious is that the theme of education appears in virtually every narrative chapter of the novel: Tom voices respect for the men who took different courses while in McAllister, Al dreams to learn to fix cars, and Connie wants to study radio once the family gets to California. Analysis of all these dreams suggests that for the characters, knowledge is both an instrument to earn one's living and increase socioeconomic status. The young Connie expresses his intent to study nights to learn the radio and become a sought-after specialist. Surprisingly, young and naïve Connie 
finds support from the narrator stressing the power of knowledge to change the world: "Behind the fruitfulness are men of understanding and knowledge, and skill, men who experiment with seed, endlessly developing the techniques for greater crops of plants whose roots will resist the million enemies of the earth... They have transformed the world with their knowledge" [16, pp. 235-236].

In some narrative parts, knowledge as an intangible asset comes into opposition with tangible assets, like land, thereby underlines the importance of ongoing self-cultivation rather than hoarding. This confrontation is apparent in the words of Casy teaching Tom that a person who "needs a million of acres to make him feel rich, seems to me he needs it 'cause he feels awful poor inside hisself, and if he's poor in hisself, there ain't no million acres gonna make him feel rich..." [16, p. 140].

In Casy's understanding, intangible assets like knowledge and self-reliance will make a person happy all the time but this does not necessarily work with tangible goods.

The character of Casy that we consider to be a key in terms of establishing and elaborating on the theme was another reason why education appears in the conceptual model. It is a well-known fact that a Christ-based figure of Jim Casy is based on Ed Ricketts, an American biologist, philosopher, and pioneer in intertidal ecology. We believe that by introducing parallelism between Casy and Rickets, Steinbeck sought to promote an idea about free spirit, knowledge, and ongoing research being the driving force behind becoming a self-reliant man and a part of a prospering community.

Conclusions. So themes constructing the concept of American Dream in the novel "The Grapes of Wrath" by J. Steinbeck include "Faith", "Land as a source of identity", "On the road", "Unity" and "Knowledge to transform the world". These themes help to create self-reliant person hierarchy. We consider that the theme of faith is the basic one, because people cannot survive without faith; being on the road is a constant process in human existence for searching better living conditions; only united people can be strong enough to stand their rights; and knowledge is a great power to transform the world for the better.

\section{References:}

1. Голенпольский Т.Г., Шестаков В.П. «Американская мечта» и американская действительность. Москва : Искусство. 1981. 208 с.

2. Зверев А.М. «Американская трагедия» и «американская мечта» (К проблеме национального идейно-художественного своеобразия литературы США) // Литература США ХХ века. Опыт типологического исследования. Москва : Наука. 1978. С. 134-208.

3. Попова Н.В. «Американская мечта»: история развития концепта и его интерпретации в романе Т. Драйзера «Американская трагедия» Международный научно-исследовательский журнал, 2017. URL: https://research-journal.org/wp-content/uploads/2017/03/03-2-57. pdf\#page $=42$.

4. Bragg J., Drayton M. The American Dream. London : Longman. 2004. 64 p.

5. Brown H. The Age of Gold. N. Dakota: Powell's Books. 2000. 147 p.

6. Featherstone M. Consumer culture and postmodernism.URL: http://dx.doi.org/10.4135/9781446288399.

7. Fontenrose J. The critical response to John Steinbeck's "The Grapes of Wrath" / edited by Barbara A. Heavilin Westport, Conn.: Greenwood Press. 2000. $357 \mathrm{p}$.

8. Hugen H. The American Dream. New York: Vintage Books. 1968. $290 \mathrm{p}$.
9. Lawrence R. Striking the Root: Essays on Liberty. New York: Vintage Books. 1995. 110 p.

10. Lutwack, L. "Introduction" In Heroic Fiction: The Epic Tradition And American Novels of the Twentieth Century. London: Feffer and Simons Inc. Carbondale and Edwardsville: Illinois univ. press. London and Amsterdam: Feffer \& Simmons. Inc. 1971. P. 64-87.

11. Miller D. City of the Century. New York: Simon \& Schuster. 1996. $263 \mathrm{p}$.

12. Murry W.R. Religious humanism, 2000. URL: https://www.meadville. edu/files/resources/v1-n2-murry-religious-humanism-461.pdf/

13. Parini J. John Steinbeck: A Biography New York Holt. 1995. 535 p.

14. Shiller R.J. The transformation of the "American Dream", 2017. URL: https://www.nytimes.com/2017/08/04/upshot/the-transformationof-the-american-dream.html.

15. Shockley S.M. "Christian Symbolism in The Grapes of Wrath" In Wicker Tedlock ed.

16. Steinbeck J. Grapes of Wrath, 1939. URL: https://genius.com/Johnsteinbeck-chapter-1-the-grapes-of-wrath-annotated/

17. Toth G. Myths and contexts in John Steinbeck's The Grapes of Wrath. Americana. E-Journal of American Studies in Hungary, 6 (1), 2010. URL: http://americanaejournal.hu/vol6nol/gabriella-toth/

18. Truslow J.A. The Epic of America. Boston Little, Brown, and company. 1931. $433 \mathrm{p}$

Насалевич Т. В., Пчела Ю. В. Теми, які створюють концепт Американської Мрії в романі «Грона гніву» Джона Стейнбека

Анотація. Стаття присвячена розкриттю тем, що створюють концепт Американської Мрії в романі «Грона гніву» американського письменника XX століття Джона Стейнбека. Коротко розповідається про виникнення концепту Американської Мрії. Представлено опис та аналіз складників концепту Американської Мрії.

Автор статті пояснює, яким чином теми, висвітлені в романі «Грона гніву», формують національну ідентичність під час кризи. Також пояснюються причини створення роману Дж. Стейнбека. Описано відмінність Американської Мрії від інших Мрій. Автор зробив спробу проаналізувати основні складові концепту Американської Мрії, надані різними вченими.

У статті представлені компоненти концепту Американської Мрії, представлені різними лінгвістами та літературознавцями. Аналіз роману Джона Стейнбека «Грона гніву» дає підстави вважати, що Американська Мрія - це потужна ідея, що містить прояв частих тем, глибокий аналіз яких дає можливість зрозуміти збереження національної ідентичності під час кризи.

У дослідженні представлена власна Модель ієрархії самостійної особистості, заснована на темах, які створюють концепт Американської Мрії: «Віра», «Земля як джерело ідентичності», «У дорозі», «Сдність» і «Знання для перетворення світу». Кожна з тем аналізується і підтримується відповідними ілюстраціями з тексту роману. Автори вважають, що тема віри є основною, оскільки людина не може вижити без віри; перебування у дорозі - це постійний процес людського існування для пошуку кращих умов життя; тільки об'єднані люди можуть бути достатньо сильними, щоб відстоювати свої права; і знання - це велика сила для перетворення світу на краще.

Ключові слова: концепт, Американська Мрія, віра, земля, дорога, єдність, знання, самостійність. 